\title{
The Impact of COVID-19 on the Teaching Work: From Face-to-Face to Virtual
}

\author{
Cristina Asuncion Lopez Ulloa ${ }^{a}$, Juan Méndez Vergaray ${ }^{b}$ and Edward Flores $^{c}$ \\ anniversidad César Vallejo, Perú (ORCID: 0000-0002-8097-5208) \\ ${ }^{b}$ Universidad César Vallejo, Perú (ORCID: 0000-0001-7286-0534) \\ 'Universidad César Vallejo, Perú (ORCID: 0000-0001-8972-5494)
}

Article History: Received: 10 November 2020; Revised 12 January 2021 Accepted: 27 January

2021; Published online: 5 April 2021

\begin{abstract}
The aim of this review is to analyze the publications on the impact of COVID-19 on the virtual work of teachers in relation to work, socio-family and mental health. To review the literature, 32 articles were examined in the following databases: Scopus, EBSCO and Scielo; in English and Spanish, between 2020-2021. The search terms were: "teachers AND Covid-19", "impact of Covid-19 on teachers", "mental health AND teachers", "stress AND COVID-19", "family AND COVID-19". In addition, for the analysis of the results, 14 articles were considered and organized in a data matrix considering the aspects: work life, socio-family and mental health of teachers; framed in the COVID-19 context. As a result, in one study, 36.1\% of teachers indicated that they were moderately satisfied with their work because they were not prepared to take on virtual education. Likewise, other authors found that levels of stress and distress were increasing, reaching very serious levels. Consequently, studies carried out on the impact of COVID-19 on teachers' work show that it has significantly affected their daily educational work, but that teachers have found coping strategies to deal with this new social and pedagogical dynamic.
\end{abstract}

Keywords: COVID-19, teachers, mental health, socio-familial, virtuality.

\section{Introduction}

\section{The great challenge of virtual education}

The origin of the COVID-19 disease in the city of Wuhan in China, the declaration of the pandemic in March 2020 and the growing contagion worldwide, caused a strong psychosocial impact in all senses, with students and children teachers immersed in it (Stoiljković, 2020). Thus, schools were closed to protect children and young people from the fearsome contagion and with this, problems arose in the teachers of how and what to teach; This is why new forms of teaching had to be implemented (Rivera et al., 2020). It is known that the teaching profession has always been carried out under difficult conditions; It is for this reason that they are constantly dissatisfied at work; The pandemic reality has given rise to a new complex and uncertain scenario, for which the working conditions and the demands of virtuality have made teaching work more complex, but at the same time constitute a challenge to empower oneself in this new reality (Salas et al. , 2020).

We all recognize that learning can be achieved in different places and with different people, that is why online learning has been chosen as an urgent measure to be a viable alternative and thus continue to provide education in these times of social isolation ( Jain et al., 2020).

In face-to-face education, learning is achieved through interaction with others, especially with peers and teachers (Rivera et al., 2020); now, at a distance, this has become more difficult. Likewise, in person, the teacher was able to get to know their students in different aspects and could detect various problems that altered learning, guiding the student and their parents to achieve improvements (Midcalf \& Boatwright, 2020), this same is being done to distance, with the participation and commitment of the family, which have become the pillar of the teaching-learning process in this new reality (Cardini et al., 2020).

However, communicative ability, which favors cooperative work, because everyone learns from everyone and gives rise to human contact, is taking place in a different way and it is difficult to adapt to the new situation; In short, face-to-face education offers many spaces and situations to socialize and build democracy, to learn to work for the common good (Aguilar, 2020) and in virtual education, small family spaces are being implemented that somehow seek solve the problem of social isolation (Crescenza et al., 2021).

The great change, going from face-to-face education to virtuality, has turned us all upside down, which is why national and international teachers were faced with different difficulties: insecurities, doubts, fears, anxiety, stress (Herrera et al., 2021); Furthermore, while organizing and executing their teaching work, they faced 
something chaotic such as the COVID-19 disease in their lives on a personal or family level (Almeida \& Dalben, 2020).

For this reason, the teachers had to install the virtual classroom in a few days to empower themselves to this new reality by adapting strategies and gradually learning to use virtual resources and get more out of the internet and social networks, since they had to use any digital medium that facilitates and brings them closer to their students, putting their resilience capacity at stake and thus being able to face distance education with other strategies and other tools (Turull, 2020).

Initially it was thought that virtual education was a complement to face-to-face education and that this situation would last for a short time, but this was not the case, teachers had to use the different resources they found on the internet: websites, social networks and what was implemented by government sites; all this with the active participation of students and the committed support of parents (Ruiz, 2020).

\section{Social isolation and its effects}

It was known that isolation and social distancing were effective in reducing the number of infected in this pandemic, but it was also necessary to recognize that it is always necessary to relate to others in order to have a satisfactory well-being despite social distancing; For this reason, it was necessary to think about those who were close and should be confined at home (García, 2020).

In the same way, when the measure of preventive and compulsory social isolation was established to avoid contagion, the routines that each one had were altered, the relationships that were established with others were shortened when it was possible to go out on the street, it was suspended face-to-face work and had to stay away from those they saw daily (Ribot et al., 2020). Furthermore, this situation of being confined at home and constantly seeing family members, produced various confrontations; because all the dynamics of coexistence that they had changed and those who did not use to be constantly at home had to get used to being there all day to be able to assume this isolation (Cisneros \& Robles, 2020).

In this way, everything became new and uncertain and due to compulsory social isolation, virtual work or telework affected the lives of teachers both at the level of physical and mental health, social and family relationships, as well as work; since, nobody was prepared to carry out distance education (Dos Santos et al., 2020).

\section{Work stress}

People going through a situation of compulsory social isolation, which does not allow them to move freely and who must maintain social distancing from others has generated mental health problems, which has been evident in symptoms such as: insomnia, anxiety, depression and stress; All of this increases when a close relative or they themselves suffer from the COVID-19 disease (Ramírez-Ortiz et al. 2020). In addition, behaviors of fear, anguish, sadness, anger or impatience are observed; these emotions are born as a way to protect life or to protect oneself from what is harmful, in this case, the COVID-19 disease (Valero et al., 2020; (Herrera et al., 2021).

It is important to note that it is not possible to foresee the consequences of COVID-19 worldwide; Since an increase in mental disorders is foreseen, everyone fears getting sick, suffers from contracting the severity of the symptoms of the disease and must continue with the social distancing that has caused serious economic difficulties because it changed the way of living, working, studying, of living with the family and the way to bond with others (García, 2020).

That is why this article addresses the effects that COVID-19 has produced in various fields of human activity, in which teachers are obviously included in their professional, social and family life; However, this reality has forced abrupt changes to adapt to this new form of existence (Martínez-Pérez \& Lezcano-Barbero, 2020; Velásquez \& Ruidiaz, 2021).

This study is important insofar as it addresses the current reality and aims to provide useful information to analyze the consequences of COVID-19 in the lives of teachers because despite these changes, they must be prepared to serve their students in a physical classroom or in a virtual one (Midcalf \& Boatwright, 2020). Thus, this inquiry will contribute to the understanding of this new normal and how it is affecting teaching work, since with the arrival of the pandemic everyone had to change their way of life in many aspects and go through a process of adaptation to the new changes (Velásquez \& Ruidiaz, 2021). In line with this reality, the emotions of education social actors, especially teachers, should be reviewed and cared for so that they can continue to perform their professional responsibilities efficiently (Aldana \& Rodríguez, 2020).

Therefore, the objective of this review is to analyze the publications made in relation to the impact of COVID-19 in the virtual work of teachers with respect to work, socio-family and mental health, describing the vicissitudes by which teachers go through in this pandemic situation. 


\section{Materials and method}

In this investigation, a review of the literature was carried out analyzing the impact of COVID-19 on the virtuality of work, social and family life and on the mental health of teachers; identifying what is known about the subject, what has already been investigated and the aspects that would be missing (Reyes, 2020).

The analysis-synthesis method was used, which allows a study of the scientific evidence found and synthesize the relevant information to show how the study was carried out. The search was carried out in English and Spanish, between 2020-2021, mainly in the database of: Scopus, EBSCO and Scielo and the search equations were, in Spanish: "teachers AND Covid-19", "impact of Covid -19 in the teacher "and" mental health AND teachers "“ stress AND COVID-19 "“ family AND COVID-19 "and in English:" teachers AND Covid-19 "," impact of Covid-19 on teachers "and" mental health AND teachers "" stress AND COVID-19 "" family AND COVID-19". The search results yielded a total of 575 documents, of which 105 were excluded due to duplicates and 435 due to considering that the title, abstract and keywords did not fit our review line and also because they were not articles; Finally, 35 investigations were selected from the total of those reviewed, of which they were: 8 in English, 23 in Spanish and 4 in Portuguese (Lam, 2016).

\section{Results}

\section{Virtuality and teaching work}

With the arrival of this pandemic worldwide, everyone's life has been harmed in all ways; That is why the teaching work changed in these times, since they suffered variations in their schedules, in their way of working and in their workload, as a result, their work was interrupted many times because the students did not They had the necessary digital tools to be served efficiently, being moderately satisfied with their work $36.1 \%$ of the total study (Martínez-Pérez \& Lezcano-Barbero, 2020).

On the other hand, in higher education, teachers and students were able to go from a face-to-face mode to a virtual one in a more comfortable way since they had basic technological knowledge because they had previously been using virtual means, such as videoconferences (Carabelli, 2020) .

However, this did not happen with all of them, since the vast majority of pre-school and primary teachers were not trained in the technology and methodology of virtual education; In addition, the students did not have the autonomy and self-determination to fulfill their responsibilities in distance education, which is why the teacher's work turned out to be more difficult to be followed by the students and therefore required more effort in their daily tasks. (Castaman \& Rodrigues, 2020).

In addition, evidence was found that the teacher presented various difficulties: the organization and implementation of virtual classes, the lack of support and advice to be able to carry out teaching through the networks and give support to parents, since if Well many were guiding their children and were very committed to their education; Others, for various reasons, were not supporting, did not communicate or disconnected and communication with them and follow-up with students became more difficult, for the efficient performance of the teacher (Ludovico et al., 2020).

All this leads to the observation that some teachers knew or already used some virtual means to be able to face this distance education, but the vast majority of teachers were not in the same situation, which is why they had to face various problems to implement virtual education (Velásquez \& Ruidiaz, 2021).

\section{Changes in social and family life}

It may be thought that doing work from home predisposes you to have more time to dedicate to other personal activities, but the sense of time and being at home due to the pandemic cannot be managed well and this causes many inconveniences in families (Cisneros \& Robles, 2020). It should be noted that in a study carried out 59.2\% of the teachers surveyed considered that virtual education was an intrusion to their privacy and family life since they had to attend to their students and parents at any time of the day and hindered their hours of rest and being with their families (Akour et al., 2020).

This is why, despite the distance education, the teachers had to take care of their own well-being and that of their family, maintaining a good diet and a positive routine of their hours dedicated to work and those that they should dedicate enjoying their family; all this following the security measures and in protection of not contracting the COVID-19 disease (García-García, 2020).

\section{Mental health in teachers}

On the other hand, university teachers in terms of the level of stress present a serious level with $89.4 \%$; Regarding the level of anguish, they present a severe level with $94.2 \%$; on the level of anxiety, they are also predominantly severe with $92.3 \%$ and on resilience, $58.9 \%$ show a medium level (Casimiro et al., 2020). In addition, $40 \%$ of teachers present depression, anxiety and extremely severe stress, this is due to the effort they make to live with COVID-19 and to fulfill their responsibilities inherent to their work (Aldana \& Rodríguez, 
2020).

Likewise, within the difficulties of teachers, which can also be called stressors, are: excessive working hours, the organization of the school and of himself, the ignorance of virtual environments, the relationship with their students and parents and like everyone else, the uncertainty about the pandemic (Oros et al., 2020).

Another aspect that affected the mental health of teachers was the problem that their students presented to continue with virtual education; Since the investigation carried out has allowed a holistic vision of what happens in education at a global level and we should talk about exclusion, since, although the government implemented virtual platforms and radio and television programs so that education continue in children and young people, they found many problems to access them; Also, the vast majority of students were alone at home and did not have the emotional support of an adult and a guide to follow the classes online, so the teachers had to do their best to respond to these situations and implement original resources and techniques to carry out their work and deal emotionally with their own problems and that of their students (Costa, (2020).

It should be noted that one of the main difficulties that the teacher had was establishing relationships with his students, through virtual platforms especially in basic education, especially at the initial level, because one of the characteristics of infants It is expressing yourself freely, expecting acceptance from the other person; Faced with this reality, the teacher had to adapt and face this situation to efficiently carry out virtual education, generating stress and anxiety in teachers (Aguilar, 2020).

Likewise, it is stated that with COVID-19, great social inequalities were increased in all aspects and that families could not preserve basic life situations; That is why, in the vast majority of cases, the teacher had to accompany his students and investigate the reason for the absence of some students, causing discomfort in them, because everyone, including them, became vulnerable actors within the society (Almeida \& Dalben, 2020). In this way, and despite their own difficulties and those of others, the teachers of the different levels had to face new challenges.

\section{Discussion}

Undoubtedly, the arrival of COVID-19 and its implications have affected everyone's lives, but not only in the current moments, but its future consequences will be reflected in the different instances of human endeavor and especially in education. . It is evident that teachers have faced and are facing various difficulties in this context of pandemic and virtual education that are evident in the organization of virtual work with the ignorance that many had about this modality; the increase in working hours and little support from some parents (Oros et al., 2020; Ludovico et al., 2020).

In the same way, teachers and students have had to face adaptation to virtual education despite initial ignorance of digital tools; However, educational actors have shown skills to overcome this obstacle by developing emotional resilience strategies to face this situation and transmit it to their students and families, achieving favorable results in coping with personal and work conflicts (Stachteas \& Stachteas, 2020).

All this caused damage in terms of mental health, since during this time of pandemic, teachers showed high levels of anxiety, anguish and stress due to the unexpected and the radical change in their work (Herrera et al., 2021; Casimiro et al., 2020; Aldana \& Rodríguez, 2020). Similarly, during the pandemic, 34\% of teachers showed a high degree of fear of getting sick or seeing a family member contract the disease, all of this is still latent, so it is necessary to pay emotional attention to teachers (Stachteas \& Stachteas, 2020).

These changes have been so abrupt and unexpected that it has taken everyone by surprise; however, various implementation strategies for virtual education have been carried out, but this is not enough since it is necessary to train teachers in relation to virtual tools to improve educational services and the quality of teaching; This pandemic reality also generated desertion and discouragement in schoolchildren, who were faced with a new virtual reality that brought economic problems for families and teachers who were forced to acquire electronic devices; Added to this scenario is the lack of reliability of the new way of evaluating students (García, 2021). This situation is the one that has not been much investigated, since the teacher and the families had their economy affected in order to be able to implement the digital tools necessary for their work performance. All this must be remedied and implemented, learning from past deficiencies because it will still have to be followed in confinement and distance education.

We have been living in a great social gap, for many years, but in these times, the digital gap has been added, which must be shortened since it is essential for the education sector, in these times of distance education that everyone has a signal digital (Díez \& Gajardo, 2020). Likewise, it is proposed to work based on three gaps: the gap in access to education, since many students, for various reasons, did not access virtual classes; the pedagogical skills and digital literacy gap as many teachers and parents were not prepared to connect digitally; the use gap, since many of the students and teachers did not have the opportunity to use technology due to lack of electronic devices or internet service (Jain et al., 2020). Thus, added to the problems of the teaching profession implementing virtual education, teachers had to assume those of their students who, due to lack of connectivity or because they were alone, could not assume the educational activities that corresponded to them (Costa, 2020; Aguilar, 2020; 
Almeida \& Dalben, 2020).

On the other hand, teachers, apart from facing the lack of technological resources and little communication with parents, also had to face the low participation of their students since they did not deliver the required work, this was confirmed by $60 \%$ of the teachers surveyed (Midcalf \& Boatwright, 2020). Then, it must be analyzed whether through virtual education it has been possible to achieve new learning in students.

\section{Conclusions}

Undoubtedly, COVID-19 with all its implications, has brought countless effects in all sectors of human endeavor, because from one moment to the next our usual way of living was disrupted. Teachers were also affected in terms of their work because they went from a face-to-face education to a distance education, from synchronous to asynchronous classes, from a classroom education to a virtual one, for which no one was prepared and had to cope with abrupt way (Reynosa et al., 2020).

Likewise, social, friends and family relationships were affected, because like everyone else, they had to carry out distancing and quarantine. In many cases, they suffered the loss of colleagues, friends and family that they had to fire silently and from a distance (Almeida \& Dalben, 2020).

Within all this, mental health was also affected since, together with the pandemic crisis, teachers also had to emotionally accompany their students and their parents. Regarding this last issue, few studies have been carried out on school teachers (Aldana \& Rodríguez, 2020).

On the other hand, the lack of connectivity, the bad signal of the networks, the lack of student equipment, the lack of support from parents for various reasons: health or work; It greatly affected the work of the teachers because they could not have continuity in communication with their students and parents and thus many times, they were worried about not being able to have comprehensive care for their students covered (Aguilar, 2020).

Finally, it is important to note that there are not enough studies that address the consequences that teachers have suffered on their physical health, since, with this new normal, they were also affected with physical and perceptual ailments, among others as a consequence of COVID- 19. Likewise, it should be investigated on the impact on the lives of teachers in terms of their economy; Since, as a result of this situation, they were forced to implement classrooms in their homes and buy devices that facilitate classes with their students, such as: computer, laptop, microphones, printers, latest generation cell phones and pay for unlimited connection plan on their cell phones.

\section{References}

[1]. Aguilar, F. (2020). Del aprendizaje en escenarios presenciales al aprendizaje virtual en tiempos de pandemia. Estudios Pedagógicos (Valdivia), 46(3), 213-223. https://doi.org/10.4067/s071807052020000300213

[2]. Akour, A., Al-Tammemi, A. B., Barakat, M., Kanj, R., Fakhouri, H. N., Malkawi, A., \& Musleh, G. (2020). The impact of the COVID-19 pandemic and emergency distance teaching on the psychological status of university teachers: A cross-sectional study in Jordan. American Journal of Tropical Medicine and Hygiene, 103(6), 2391-2399. https://doi.org/10.4269/ajtmh.20-0877

[3]. Aldana, J., \& Rodríguez, N. (2020). Depresión, ansiedad y estrés por COVID -19 en actores educativos. Revista Arbitrada Interdisciplinaria de Ciencias de La Salud. Salud y Vida, 4(8), 6. https://doi.org/10.35381/s.v.v4i8.932

[4]. Almeida, L. C., \& Dalben, A. (2020). Organizar el trabajo pedagógico en tiempo de COVID-19: en el límite del (im)posible. Educ. Soc, 2020. https://doi.org/10.1590/ES.239688

[5]. Carabelli., P. (2020). Respuesta al brote de COVID-19: tiempo de enseñanza virtual. InterCambios. Dilemas y Transiciones de La Educación Superior, 7(2), 189-198. https://doi.org/10.2916/inter.7.2.16

[6]. Cardini, A., Bergamaschi, A., D’Alessandre, V., Torre, E., \& Ollivier, A. (2020). Educar en pandemia: Entre el aislamiento y la distancia social. Banco Interamericano de Desarrollo, 1-84.

[7]. Casimiro, W., Casimiro, C., Barbachán, E., \& Casimiro, J. (2020). Stress, anguish, anxiety and resilience of university teachers in the face of covid-19. Utopia y Praxis Latinoamericana, 25(Extra 7), 453-464. https://doi.org/10.5281/zenodo.4009790

[8]. Castaman, A. S., \& Rodrigues, R. A. (2020). Educação a Distância na crise COVID - 19: um relato de experiência. Research, Society and Development, 9(6), e180963699. https://doi.org/10.33448/rsdv9i6.3699

[9]. Cisneros, J., \& Robles, A. (2020). El tiempo en tiempos de confinamiento de Covid-19. El Cotidiano, julio-agos(cambio social), 97-110. https://www.aytopadules.com/estacion/Current_Vantage_Pro.htm

[10]. Costa, R. (2020). Desafios Pedagógicos: antes y en la Pandemia COVID 19. Temas Em Educação e 
Saúde, 16(2), 594-606. https://doi.org/10.26673/tes.v16i2.14061

[11]. Crescenza, G., Fiorucci, M., Rossiello, M., \& Stillo, L. (2021). Education and the Pandemic : Distance Learning and the School-Family Relationship. Research in Education and Learning Innovation Archives, 26, 73-86. https://doi.org/10.7203/realia.26.18078

[12]. Díez, E., \& Gajardo, K. (2020). Educación y evaluación en tiempo de pandemia: la situación de España. Multidisciplinary Journal of Educational Research, 10(2), 102-134. https://doi.org/10.4471/remie.2020.5604

[13]. Dos Santos, B., Scorsolini-Comin, F., \& Barcellos, R. (2020). Ser docente en el contexto de la pandemia de COVID-19: reflexiones sobre la salud mental. Index de Enfermeria, 29(3), e3773. https://ciberindex.com/index.php/ie/article/view/e12983

[14]. García-García, M. (2020). La docencia desde el hogar. Una alternativa necesaria en tiempos del Covid 19. Polo Del Conocimiento (Edición Núm. 44), 5(04), 304-324. https://doi.org/10.23857/pc.v5i3.1318

[15]. García, A. M. (2020). La escuela en tiempos de Pandemia. In Question/Periodismo y Comunicación (Vol. 1, Issue mayo). Universidad Nacional de La Plata. https://doi.org/10.24215/16696581e313

[16]. García, J. (2020). Mental health research during the COVID-19 pandemic. In Revista Colombiana de Psiquiatria (Vol. 49, Issue 4, pp. 221-222). Elsevier Doyma. https://doi.org/10.1016/j.rcp.2020.11.001

[17]. García, L. (2021). COVID-19 y educación a distancia digital: preconfinamiento, confinamiento y posconfinamiento. RIED. Revista Iberoamericana de Educación a Distancia, 24(1), 9-32. https://doi.org/10.5944/ried.24.1.28080

[18]. Herrera, N., Sanchez, S., Méndez, J., Rivera, E., \& Reynosa, E. (2021). Anxiety and aggressiveness in Peruvian postgraduate students in COVID-19 context. European Journal of Molecular \& Clinical Medicine, 08(03), 713-726. https://ejmcm.com/article_9494.html

[19]. Jain, S., Lall, M., \& Singh, A. (2020). Teachers' Voices on the Impact of COVID-19 on School Education: Are Ed-Tech Companies Really the Panacea? Contemporary Education Dialogue, 18(1), 5889. https://doi.org/10.1177/0973184920976433

[20]. Lam, R. (2016). La redacción de un artículo científico. In Revista Cubana de Hematología, Inmunol y Hemoterapia (Vol. 32, Issue 1). http://scielo.sld.cu

[21]. Ludovico, F., Molon, J., Franco, S., \& Barcellos, P. (2020). COVID-19: DESAFIOS DOS DOCENTES NA LINHA DE FRENTE DA EDUCAÇÃO. Interfaces Científicas - Educação, 10(1), 58-74. https://doi.org/10.17564/2316-3828.2020v10n1p58-74

[22]. Martínez-Pérez, A., \& Lezcano-Barbero, F. (2020). Percepción del Impacto de la Covid-19 en los Profesionales de la Educación Social que Trabajan con Menores. Revista Internacional de Educación Para La Justicia Social, 9(3), 223-243. https://doi.org/10.15366/riejs2020.9.3.012

[23]. Midcalf, L., \& Boatwright, P. (2020). Teacher and Parent Perspectives of the Online Learning Environment Due to COVID-19. Delta Kappa Gamma Bulletin, 87(1), 24.

[24]. Oros, L., Vargas, N., \& Chemisquy, S. (2020). Estresores docentes en tiempos de pandemia: Un instrumento para su exploración. Revista Interamericana de Psicología/Interamerican Journal of Psychology, 54(3), e1421. https://doi.org/10.30849/ripijp.v54i3.1421

[25]. Ramírez-Ortiz, J., Castro-Quintero, D., Lerma-Córdoba, C., Yela-Ceballos, F., \& Escobar-Córdoba, F. (2020). Consecuencias De La Pandemia Covid 19 En La Salud Mental Asociadas Al Aislamiento Social. Revista Scielo Preprints, 21. https://doi.org/10.1590/SciELOPreprints.303

[26]. Reyes, H. (2020). Artículos de Revisión. Revista Médica Chile, 148, 103-108. https://scielo.conicyt.cl/pdf/rmc/v148n1/0717-6163-rmc-148-01-0103.pdf

[27]. Reynosa, E., Rivera, E., Rodríguez, D., \& Bravo, R. (2020). Adaptación docente educativa en el contexto COVID-19: una revisión sistemática. Journal Conrado, 16(77), 141-149. https://conrado.ucf.edu.cu/index.php/conrado/article/view/1580/1563

[28]. Ribot, V., Chang, N., \& Gonzáles, A. (2020). Efectos de la COVID-19 en la salud mental de la población. Revista Habanera de Ciencias Mèdicas. http://scielo.sld.cu/scielo.php?script=sci_arttext\&pid=S1729519X2020000400008

[29]. Rivera, E., Méndez, J., Huayta, Y., Garro-Aburto, L., \& Reynosa, E. (2020). Educational Inclusion in Times Of COVID-19: Talking with Female Inclusive Teachers in Lima-Peru. International Journal of Pharmaceutical Research, 12(01). https://doi.org/10.31838/ijpr/2020.12.01.408

[30]. Ruiz, G. (2020). COVID-19: Pensar la educación en un escenario inédito. Revista Mexicana de Investigacion Educativa, 25(85), 229-237.

[31]. Salas, G., Santander, P., Precht, A., Scholten, H., Moretti, R., \& López-López, W. (2020). COVID-19: impacto psicosocial en la escuela en Chile. Desigualdades y desafíos para Latinoamérica. Avances En Psicología Latinoamericana, $38(2)$,

$1-17$. https://revistas.urosario.edu.co/index.php/apl/article/view/9404

[32]. Stoiljković, Č. (2020). The impact of the covid-19 pandemic on the educational work of kindergarten teachers. International Journal of Cognitive Research in Science, Engineering and Education, 8(3), 123- 
133. https://doi.org/10.23947/2334-8496-2020-8-3-123-133

[33]. Turull, M. (2020). Docencia en tiempos de Covid 19. Revista de Educación y Derecho., O(22). https://doi.org/10.1344/REYD2020.22.32347

[34]. Valero, N., Velez, M., Duran, A., \& Torres, M. (2020). Afrontamiento del COVID-19: estres,miedo,ansiedad y depresion. Enfermeria Investiga. Investigacion, Vinculacion, Docencia y Gestion, 5(3), 63-70. file:///C:/Users/Maria Jose/OneDrive/Escritorio/913-110-2157-1-1020200706.pdf

[35]. Velásquez, S., \& Ruidiaz, K. (2021). La educación en tiempo de pandemia COVID 19: ¿ realidad o ficción ? Revista Cuidarte, 12(1). https://doi.org/10.15649/cuidarte.1336 